\title{
China and the Trans-Pacific Partnership Agreement: Misfit or Missed Opportunity?
}

\section{Bala Ramasamy and Matthew C.H. Yeung ${ }^{1}$}

\section{Abstract}

If it eventuates the Trans-Pacific Partnership agreement (TPP) will include major economic powerhouses like the US and Japan, but China - the elephant in the room - has been excluded. Our evaluation of how China might fare in the TPP finds that the agreement would be a poor fit at the current stage of China's economic development. Although China would gain both in terms of trade and a reform timetable, some features of this 21 st-century agreement - the assistance given to state-owned enterprises, the standards for labour rights, protection of multinationals against the state and competition laws - would be stumbling blocks in the negotiation process. Thus, being left out of the TPP is no big loss for China.

\section{Introduction}

The Trans-Pacific Partnership (TPP) agreement is being sold as a 21st-century free-trade agreement (FTA) involving 12 member countries: Australia, Brunei, Canada, Chile, Japan, Malaysia, Mexico, New Zealand, Peru, Singapore, the US and Vietnam. (In 2014, the TPP's 12 economies made up about 36 per cent of the world's GDP and about 25 per cent of world trade in goods and services.) The agreement goes beyond providing member countries market access to goods, services and investment (as covered by most other trade agreements

1 China Europe International Business School; Open University of Hong Kong; myeung@ouhk.edu.hk. 
such as the China-ASEAN FTA). It also includes other trade-related issues, such as government procurement, competition involving state-owned enterprises (SOEs), labour and the environment. Negotiations began in March 2010 and were concluded in February 2016, with ratification by respective national governments to happen within two years.

Absent was the 'elephant in the room': China. China is the world's largest trader and the 12 TPP member countries made up about one-third of China's trade in 2013. Although China was invited to join the TPP in 2012 by the then US Secretary of State Hillary Clinton, there is reason to believe that the high standards ordained by the TPP were designed to keep China out (Hsu 2015). This was implied by President Obama in his State of the Union address in January 2016: 'With TPP, China does not set the rules in that region; we do.'

China has its own plans to increase its influence in the region, playing a leading role in the Regional Comprehensive Economic Partnership (RCEP), which comprises the 10 member states of ASEAN, Australia, India, Japan, New Zealand, South Korea and China. The 'One Belt, One Road' initiative would link China with Central and West Asia as well as the Middle East and Europe. The establishment of the Asian Infrastructure Investment Bank and the New Development Bank (or BRICS Development Bank) are also China's initiatives to increase its economic and political influence, particularly among developing countries.

The purpose of this paper is to evaluate China's exclusion or rejection from TPP membership. To what extent does China lose out by being left out of the agreement? Are the requirements and coverage of the TPP too sensitive for China? We attempt to answer these questions by evaluating the trade patterns of China and the TPP members and delving into the TPP agreement signed by member countries, highlighting chapters that contain issues that could have been stumbling blocks for China in the negotiation stages. However, the shape the TPP will take after the Obama administration is yet to be seen, as the victorious candidate for the US presidency has had harsh words on the current agreement.

We conclude that at the current stage of the Chinese economy, the TPP may be a little too far reaching and that China's other international initiatives, such as the 'One Belt, One Road' initiative, as well as its sheer size, will reduce the losses of being left out of the TPP. 


\section{China and the TPP: A missed opportunity?}

How important is the TPP to member countries? Recent estimates by Petri and Plummer (2016) have concluded that most members will gain from the agreement. The US will find its annual real income increase by 0.5 per cent of GDP, while annual exports will increase by 9.1 per cent in 2030. The exports of Japan, Vietnam and Malaysia are to increase by 23.2 per cent, 30.1 per cent and 20.1 per cent respectively in 2030. But non-members will gain little. China is expected to gain only 0.2 per cent when the agreement is concluded in 2030 .

Table 1: China's exports and imports (merchandise goods) to TPP members, 2013

\begin{tabular}{|l|c|c|c|c|c|c|}
\hline & \multicolumn{3}{|c|}{ China's exports to } & \multicolumn{3}{c|}{ China's imports from } \\
\hline TPP members & $\begin{array}{c}\text { in US\$ } \\
\text { billions }\end{array}$ & $\begin{array}{c}\text { \% of exports } \\
\text { to all TPP } \\
\text { countries }\end{array}$ & $\begin{array}{c}\text { \% of total } \\
\text { exports }\end{array}$ & $\begin{array}{c}\text { US\$ } \\
\text { billions }\end{array}$ & $\begin{array}{c}\text { \% of imports } \\
\text { from all TPP } \\
\text { countries }\end{array}$ & $\begin{array}{c}\text { \% of total } \\
\text { imports }\end{array}$ \\
\hline United States & 410.8 & 48.9 & 18.0 & 150.5 & 27.7 & 9.0 \\
\hline Japan & 135.8 & 16.2 & 6.0 & 143.0 & 26.3 & 8.5 \\
\hline Vietnam & 66.3 & 7.9 & 2.9 & 25.1 & 4.6 & 1.5 \\
\hline Singapore & 53.1 & 6.3 & 2.3 & 27.5 & 5.1 & 1.6 \\
\hline Malaysia & 44.1 & 5.3 & 1.9 & 53.2 & 9.8 & 3.2 \\
\hline Australia & 40.3 & 4.8 & 1.8 & 73.8 & 13.6 & 4.4 \\
\hline Mexico & 33.8 & 4.0 & 1.5 & 10.0 & 1.9 & 0.6 \\
\hline Canada & 29.4 & 3.5 & 1.3 & 26.2 & 4.8 & 1.6 \\
\hline Chile & 13.2 & 1.6 & 0.6 & 18.6 & 3.4 & 1.1 \\
\hline Peru & 6.3 & 0.8 & 0.3 & 8.1 & 1.5 & 0.5 \\
\hline New Zealand & 4.9 & 0.6 & 0.2 & 6.5 & 1.2 & 0.4 \\
\hline Brunei & 1.4 & 0.2 & 0.1 & 0.09 & 0.02 & 0.01 \\
\hline TPP & 840.0 & & 36.8 & 543.3 & & 32.3 \\
\hline World & 2281.8 & & & 1681.6 & & \\
\hline
\end{tabular}

Source: unctadstat.unctad.org/wds/

Table 1 shows China's trade of merchandise goods with members of the TPP in 2013. This indicates that the 12 countries of the TPP make up about one-third of China's trade. However, the US stands out in that it makes up about half of the exports to TPP members, and about one-quarter of imports. Japan and Australia are also quite important but countries from Latin America and smaller countries in Asia are quite insignificant. China is already in some sort of negotiation with other important TPP members such as Japan and Australia (for example, 
via the RCEP). This suggests that being left out of the TPP is essentially a lost opportunity for China to bolster its trade links with the US by securing an FTA with the world's largest market. An agreement with the US could also explain the motivation of smaller countries such as Malaysia and Vietnam in joining the TPP, as they would lack the bargaining power when negotiating alone with the US.

Table 2 shows the Trade Complementarity Index (TCI) between China and the US with member countries of the TPP and the RCEP in 2013. ${ }^{2}$ This index measures how well the structures of a pair of country's imports and exports match. A value of zero indicates that no goods exported by one country are imported by the other; 1.0 indicates the export and import structures exactly match. Thus, a higher value indicates that the export profile of one country complements the import profile of its partner. Table 2 shows that the TCI is marginally greater for China with the TPP $(0.49)$ compared to the RCEP $(0.43)$. This is also the case for the US, albeit larger. The TCI is also relatively large for US-China trade (between 0.55 and 0.57). We conclude that both China and the US would have gained significantly from China's inclusion in the TPP. Petri, Plummer and Zhai (2014) estimated that a China-US FTA could generate a greater gain for China than the RCEP, and also greater gains for the US than a TPP without China, simply because the two countries complement each other.

It appears that China and the US have lost an excellent opportunity to increase bilateral trade flows, and thus provide a much-needed impetus for greater economic activity in their respective nations.

2 The TCI is the sum of the absolute value of the difference between the import shares and the export shares (at three-digit SITC) of the pair of countries, divided by two.

$\operatorname{Se}_{j} m_{k}=1-\frac{\sum_{i}\left|E_{i j}-M_{i k}\right|}{2}$

$\mathrm{Se}_{j} m_{k}=$ the index of trade complementarity of exporter $j$ with importer $k$

$i=$ goods in 3-digit SITC

$j=$ exporter (i.e. China or the US)

$k=$ importer (countries in the TPP or RCEP)

$E_{i j}=$ the share of goods $i$ in country $j$ 's total exports to the world

Mik = the share of goods $i$ in country $k$ 's total imports from the world 
Table 2: Trade Complementarity Index

\begin{tabular}{|l|c|c|}
\cline { 2 - 3 } \multicolumn{1}{c|}{} & \multicolumn{2}{c|}{ EXPORTER } \\
\hline IMPORTER & China & United States \\
\hline China & - & 0.55 \\
\hline Mexico & 0.58 & 0.69 \\
\hline United States & 0.57 & - \\
\hline Australia & 0.52 & 0.65 \\
\hline Vietnam & 0.51 & 0.59 \\
\hline Canada & 0.51 & 0.69 \\
\hline Chile & 0.50 & 0.62 \\
\hline New Zealand & 0.49 & 0.59 \\
\hline Thailand & 0.48 & 0.58 \\
\hline Peru & 0.48 & 0.62 \\
\hline Malaysia & 0.47 & 0.62 \\
\hline Japan & 0.46 & 0.52 \\
\hline Indonesia & 0.45 & 0.63 \\
\hline Brunei & 0.43 & 0.55 \\
\hline South Korea & 0.43 & 0.54 \\
\hline Singapore & 0.42 & 0.52 \\
\hline Philippines & 0.40 & 0.55 \\
\hline Lao PDR & 0.39 & 0.49 \\
\hline Cambodia & 0.36 & 0.44 \\
\hline Myanmar & 0.35 & 0.44 \\
\hline India & 0.31 & 0.44 \\
\hline TPP & 0.49 & 0.60 \\
\hline RCEP & 0.43 & 0.54 \\
\hline
\end{tabular}

Source: unctadstat.unctad.org/wds/

\section{China and the TPP: A misfit?}

Petri, Plummer and Zhai (2014) compared FTAs involving the US and those involving ASEAN. They found that agreements involving the US (for example, the US-Singapore FTA and US-South Korea FTA) included issues like competition, intellectual property rights, government procurement, the environment and labour. Mooted agreements with ASEAN (for example, the China-ASEAN FTA), on the other hand, emphasise dispute resolution and cooperation. The templates of the agreements are skewed towards the nature of the economies negotiating the agreements - whether emerging markets or advanced economies. Since the TPP is an agreement involving both types of economies, it has to be more complex, with sufficient room for bargaining. If China had chosen to be part 
of the TPP, the negotiations would have been slow and perhaps have ended without agreement because of the many sensitive issues involved. We discuss below some of the potential stumbling blocks.

\section{State-owned enterprises (SOEs)}

An important chapter in the TPP agreement is one that concerns SOEs, specifically those that are engaged in commercial activities. The agreement requires that those SOEs engaged in business with commercial considerations will not be allowed to receive non-commercial assistance from their respective governments when the SOE is operating in partner countries. In other words, no form of subsidy should be provided to an SOE for its international business expansion. The intention of this is to ensure that competition between an SOE and a private enterprise in a host country takes place on a level playing field.

SOEs are the bedrock of the Chinese economy. They have played a critical role in national economic development as well the 'go global' strategy (Yu 2014). In 2015, it was reported that there are 150,000 SOEs in China: collectively, they control US $\$ 17$ trillion in assets and employ more than 35 million people (Financial Times 2015). About 1,000 are listed on the Shanghai or Shenzhen Stock Exchanges, indicating that they are commercial in nature. More than 150 of these are managed by the central government (through the State-owned Assets Supervision and Administration Commission, SASAC), and these include some of the largest companies in the world, such as the Agricultural Bank of China, CNPC and Sinopec. Prior to 2004, only state-owned firms were allowed to engage in international investment. These SOEs are assisted in various ways, including being given preferential interest rates, by the Chinese Government (Sauvant and Chen 2014). Although some countries were able to get exemptions for their powerful cooperatives (notably, New Zealand for Fonterra), it would have been an uphill battle for China to negotiate similar exemptions for so many of its SOEs engaged in various international operations in TPP member countries.

\section{Transparency and anti-corruption}

The chapter in the TPP agreement on transparency and anti-corruption measures addresses efforts to reduce bribery and corruption in trade and investments. It calls for transparent information on the laws, regulations and other rules affecting trade and investment. It commits TPP partners to write and enforce anti-bribery laws.

The impact of bribery and corruption on international trade is well known. In a study of more than 100 countries, De Groot et al. (2004) used the World Bank Governance Indicators to show that institutional quality can have a significant positive impact on trade flows. De Jong and Bogmans (2011) also conclude that corruption generally hampers trade. Shirazi (2012: 446) states that: 
a significant reduction in the perception of corruption may have as much, if not more, of an impact on international trade as favourable labor laws, tax rates and capital (currency) control measures.

Thus, an agreement that encourages the reduction of corruptive practices in international trade is obviously welcomed.

China, however, is quite well known for its dubious business practices. Table 3 extracts the Corruption Perception Index of TPP members and China. This index, developed by Transparency International, ranks countries on the degree of corruption in the public sector. Only two TPP countries - Vietnam and Mexico - ranked below China in 2014. The TPP also includes two of the least corrupt countries: New Zealand and Singapore. Although one can argue that membership in the TPP can raise the bar for China's efforts at eradicating corruption, the gap between China and important partners (the US and Japan) are significant. The TPP can be a platform for these countries to accuse China of lacklustre anti-corruption efforts, which could be perceived by China as interference in domestic issues.

Table 3: Corruption Perception Index

\begin{tabular}{|l|c|c|c|c|}
\hline & Rank & \multicolumn{3}{|c|}{ Scores } \\
\hline Country & 2014 & 2014 & 2013 & 2012 \\
\hline New Zealand & 2 & 91 & 91 & 91 \\
\hline Singapore & 7 & 84 & 86 & 87 \\
\hline Canada & 10 & 81 & 81 & 84 \\
\hline Australia & 11 & 80 & 81 & 85 \\
\hline Japan & 15 & 76 & 74 & 77 \\
\hline United States & 17 & 74 & 73 & 73 \\
\hline Chile & 21 & 73 & 71 & 72 \\
\hline Malaysia & 50 & 52 & 50 & 49 \\
\hline Peru & 85 & 38 & 38 & 38 \\
\hline China & 100 & 36 & 40 & 39 \\
\hline Mexico & 103 & 35 & 34 & 34 \\
\hline Vietnam & 119 & 31 & 31 & 31 \\
\hline
\end{tabular}

\section{* Except Brunei}

Note: The Corruption Perception Index ranks countries and territories based on how corrupt their public sector is perceived to be. The score indicates the perceived level of public sector corruption on a scale of 0 (highly corrupt) to 100 (very clean). A country or territory's rank indicates its position relative to the other countries and territories in the index.

Source: www.transparency.org/cpi2014 


\section{Labour and intellectual property rights (IPR)}

The chapter on labour requires TPP partners to adopt a legal framework that upholds fundamental labour rights as recognised by the International Labour Organization (ILO). This includes freedom of association, the right to collective bargaining, the elimination of forced labour, the abolition of child labour, the elimination of employment discrimination, as well as laws that govern acceptable conditions of work. The inclusion of labour issues in an FTA is rare since labour rights are considered to be a 'domestic issue' and interference by external parties jeopardises the sovereignty of individual members. In this regard, the TPP can be considered bold. The implication of this chapter for Malaysia, for instance, includes amendments to its labour laws to allow formation of labour unions, limiting government discretion in registering and cancelling a labour union, as well as removing restrictions on the subjects that can be collectively bargained. Vietnam will have to allow workers to establish independent unions with full autonomy without interference from the state.

Similar to Vietnam, China's labour laws, while allowing freedom of association, require all trade unions to be affiliated with the All-China Federation of Trade Unions, which is an agency of the Chinese Communist Party. The chapter on labour would have been a contentious issue between China and the US, an issue that may not have been easily resolved.

The TPP also raises the bar for the protection of IPR above the accepted norm embodied in the TRIPS ${ }^{3}$ Agreement. There are accusations that the TPP expands the scope of patentability, particularly in the case of pharmaceuticals, and thus has negative implications for public health and access to medicine in developing members. While many accuse China of IP infringements, the issue is more related to the enforcement of the laws, rather than the laws themselves. In fact, Drahos (2016) has argued that China may have welcomed these higher standards in IPR as, since 2010, more than half of the annual increase in global trademark filing activity originates from China. China would also be keen to protect the IP of its own homegrown companies as they venture abroad. 


\section{Free and open competition}

A common philosophy that cuts across a number of chapters of the TPP is free competition among businesses domiciled within the TPP countries. In the chapter on government procurement, for instance, firms from any TPP country will be allowed to bid for government contracts, as all domiciled firms should be given equal access to information and treatment. In the Technical Barriers to Trade (TBT) chapter, testing and certification awarded by an assessment body in one country should be accepted in other countries as well. The chapter on competition generally calls for member countries to reach the standards practised in countries such as Singapore and New Zealand, known for their ease of doing business. In the World Bank rankings of Doing Business in 2016, China was lower than all TPP partners except Vietnam (see Table 4). Given that four of the 12 members are in the top 10 of these rankings, the high standards of competition in the TPP agreement is not surprising. China would have had to negotiate hard to get exemptions for its SOEs and SMEs from these opencompetition clauses and chapters.

\section{Investor-State Dispute Settlement (ISDS)}

The ISDS is a system whereby an investing company can seek compensation from a host country if its property rights have been violated. The system allows multinational companies (MNCs) to seek justice from arbitration tribunals such as the World Bank's International Centre for the Settlement of Investment Disputes (ICSID), which are considered neutral. When the MNC is suing the host government for breach of the rules in an agreement (an FTA or bilateral agreement), seeking impartial arbitration is sometimes preferred to a judicial system within the host country. This is particularly true if the host country's justice system is known for its lack of impartiality. The ISDS has been included in several FTAs recently because it offers assurance to MNCs that the chance of expropriation by host governments is greatly reduced (Jandhyala 2016). However, the ISDS is frowned upon by others, who see it as giving MNCs a means of circumventing government regulations and policies (Farrell 2015).

If China had been a party to the TPP, it could be argued that MNCs from partner countries such as the US, Japan and Canada would have lobbied their governments strongly for the inclusion of ISDS, which would have forced the Chinese Government to be accountable for any discriminatory actions. Table 5 shows how China fares against TPP countries with regards to the rule of law and, in particular, the regulatory enforcement component. China is ranked among the lowest in the overall scores, particularly on expropriation without adequate compensation. 
AGENDA, VOLUME 23, NUMBER 1, 2016

\begin{tabular}{|c|c|c|c|c|c|c|c|c|c|c|c|c|c|c|}
\hline 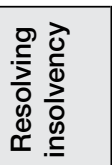 & $\hat{\sim}$ & $\bar{m}$ & $\sim$ & 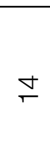 & $\stackrel{\varphi}{\sim}$ & $\stackrel{L}{q}$ & $\sim$ & $\stackrel{\infty}{\sim}$ & $\stackrel{\infty}{\infty}$ & N & $\stackrel{\infty}{\infty}$ & 伿 & 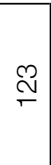 & 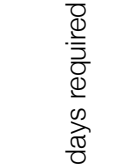 \\
\hline 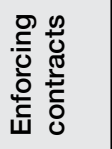 & - & $\stackrel{20}{\longrightarrow}$ & $\bar{\sim}$ & $\checkmark$ & g & $\underset{\forall}{\forall}$ & 5 & $\tau$ & $\stackrel{\bullet}{0}$ & \& & $\stackrel{m}{\leftarrow}$ & 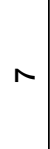 & $\stackrel{\nabla}{N}$ & 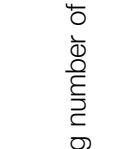 \\
\hline 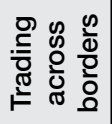 & ما & $\approx$ & $\stackrel{\mathscr{R}}{0}$ & $\stackrel{\sim}{\forall}$ & $\sigma$ & m & $\stackrel{\mathbb{N}}{\sim}$ & ๙ & ल) & 요 & $\stackrel{\varphi}{\leftarrow}$ & స్ ָे & $\begin{array}{l}\infty \\
\stackrel{0}{c}\end{array}$ & 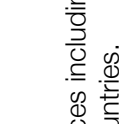 \\
\hline 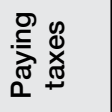 & م & $\approx$ & $\stackrel{M}{\Omega}$ & $\stackrel{\sim}{\forall}$ & $\sigma$ & ๓ & $\underset{\mathbb{N}}{\mathbb{N}}$ & ๙ & लె & 요 & $\stackrel{\oplus}{\sim}$ & $\stackrel{\widetilde{\sigma}}{\sim}$ & \begin{tabular}{l}
$\infty$ \\
0 \\
\hdashline
\end{tabular} & $\begin{array}{l}. \frac{5}{1} \\
\frac{1}{3} \\
0 \\
0\end{array}$ \\
\hline 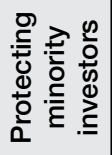 & - & - & $\stackrel{m}{m}$ & $\mathscr{8}$ & 0 & $\nabla$ & $\ddot{ల}$ & $\hat{\imath}$ & @) & g & ঙे & $\stackrel{\Xi}{\varpi}$ & $\underset{\sim}{\mathbb{N}}$ & $\begin{array}{l}0 \\
.0 \\
\frac{0}{5} \\
\frac{1}{5}\end{array}$ \\
\hline 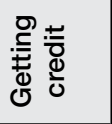 & $\stackrel{\infty}{\Gamma}$ & $\tau$ & $\sim$ & ما & $\wedge$ & $\stackrel{\infty}{\sim}$ & R & ما & R & $\stackrel{\circ}{\leftarrow}$ & R & $\stackrel{R}{R}$ & $\stackrel{\infty}{\sim}$ & 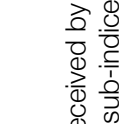 \\
\hline 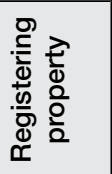 & $\stackrel{\wedge}{ᄃ}$ & - & ले & f & $\stackrel{\mathcal{V}}{\checkmark}$ & 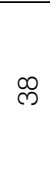 & $\stackrel{\infty}{+}$ & $\stackrel{\varnothing}{\circ}$ & $\underset{\llcorner}{\infty}$ & $\stackrel{\text { m }}{m}$ & $\stackrel{\infty}{+}$ & $\mathscr{q}$ & $\underset{\infty}{\infty}$ & 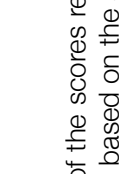 \\
\hline 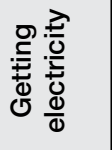 & 0 & ल & f & (્) & $\stackrel{2}{\circ}$ & $\stackrel{m}{\longrightarrow}$ & $\stackrel{\nabla}{\ulcorner}$ & $\stackrel{N}{N}$ & ז & ర్ & $\stackrel{\infty}{\varnothing}$ & ชั & $\stackrel{\infty}{\circ}$ & 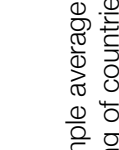 \\
\hline 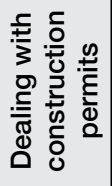 & - & $\infty$ & ల్ల & $\nabla$ & గి & $\stackrel{\llcorner}{\Gamma}$ & $\stackrel{\infty}{\infty}$ & $\hat{\theta}$ & $\stackrel{\sim}{\sim}$ & $\stackrel{\infty}{+}$ & $\bar{N}$ & 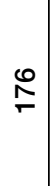 & 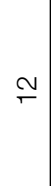 & 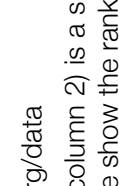 \\
\hline 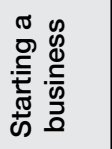 & 으 & - & g & $\mp$ & $m$ & $\stackrel{\nabla}{\ulcorner}$ & $\bar{\infty}$ & 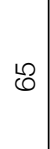 & $\widetilde{\sigma}$ & ă & 穴 & 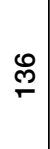 & $\stackrel{\sigma}{\square}$ & 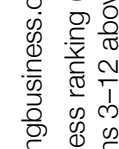 \\
\hline 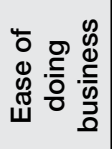 & $\tau$ & $\sim$ & $\wedge$ & $\stackrel{m}{\longrightarrow}$ & $\stackrel{\nabla}{\leftarrow}$ & $\stackrel{\infty}{\leftarrow}$ & ले & $\stackrel{\infty}{\infty}$ & $\stackrel{\infty}{+}$ & 요 & ১ & ১ & ৪ & 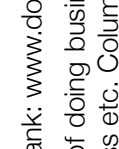 \\
\hline 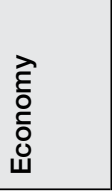 & $\begin{array}{l}\frac{0}{0} \\
\frac{0}{0} \\
\frac{0}{0} \\
\frac{\bar{c}}{\omega}\end{array}$ & 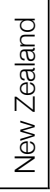 & 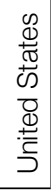 & 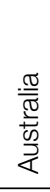 & $\begin{array}{l}\frac{\pi}{0} \\
\frac{\pi}{0} \\
\frac{\pi}{0}\end{array}$ & 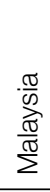 & 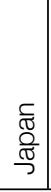 & $\begin{array}{l}0 \\
\frac{0}{x} \\
\frac{0}{2} \\
\end{array}$ & $\frac{\stackrel{0}{\overline{\bar{O}}}}{\frac{0}{O}}$ & $\underset{\frac{0}{0}}{\frac{5}{2}}$ & 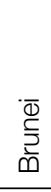 & : & 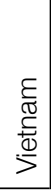 & 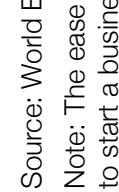 \\
\hline
\end{tabular}




\begin{tabular}{|c|c|c|c|c|c|c|c|c|c|c|c|c|c|c|c|}
\hline 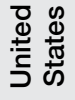 & $\begin{array}{l}\frac{m}{2} \\
\stackrel{0}{0}\end{array}$ & 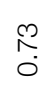 & $\widehat{0}$ & $\begin{array}{l}\vec{b} \\
\infty \\
0 \\
0\end{array}$ & $\stackrel{8}{\bullet}$ & $\begin{array}{l}\stackrel{9}{1} \\
0\end{array}$ & 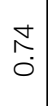 & $\begin{array}{l}0 \\
\stackrel{0}{x} \\
\stackrel{0}{0} \\
\sum\end{array}$ & $\stackrel{\text { fे }}{\circ}$ & مْ & $\stackrel{\text { }}{\stackrel{0}{*}}$ & זొ & \begin{tabular}{l} 
F \\
\multirow{0}{*}{}
\end{tabular} & $\stackrel{\infty}{\stackrel{\infty}{\circ}}$ & $\begin{array}{l}10 \\
0 \\
0\end{array}$ \\
\hline $\begin{array}{l}\frac{\pi}{0} \\
\frac{\pi}{\pi} \\
\frac{\pi}{\pi} \\
0\end{array}$ & 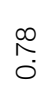 & $\begin{array}{l}\hat{A} \\
\hat{0}\end{array}$ & $\begin{array}{l}? \\
\stackrel{R}{0}\end{array}$ & 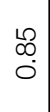 & 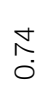 & $\begin{array}{l}\mathcal{M} \\
0\end{array}$ & $\begin{array}{l}\bar{\infty} \\
0 \\
0\end{array}$ & 蛋 & $\stackrel{\infty}{+}$ & $\begin{array}{l}0 \\
\stackrel{0}{0} \\
0\end{array}$ & 占 & $\stackrel{g}{+}$ & مُ & ๗్లా & $\begin{array}{l}\infty \\
\dddot{\Upsilon} \\
0\end{array}$ \\
\hline
\end{tabular}

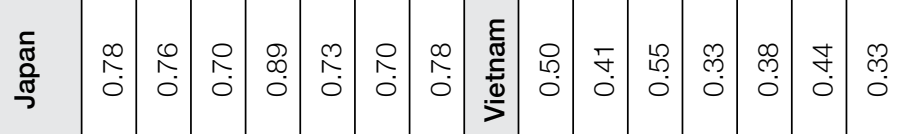

$\frac{t}{0}$
$\frac{0}{d}$

\begin{tabular}{|c|c|c|c|c|c|c|c|c|c|c|c|c|c|c|c|}
\hline 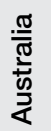 & $\begin{array}{l}0 \\
\infty \\
0 \\
0\end{array}$ & $\begin{array}{l}\bar{\alpha} \\
0 \\
0\end{array}$ & $\begin{array}{l}\stackrel{\infty}{\stackrel{0}{0}} \\
0\end{array}$ & $\begin{array}{l}\text { ठे } \\
\text { ठे }\end{array}$ & $\hat{A}$ & $\begin{array}{l}\stackrel{N}{N} \\
\stackrel{0}{0}\end{array}$ & $\begin{array}{l}\mathbb{2} \\
0 \\
0 \\
0\end{array}$ & $\frac{2}{0}$ & $\begin{array}{l}0 \\
0 \\
0 \\
0\end{array}$ & $\begin{array}{l}0 \\
0 \\
0 \\
0\end{array}$ & $\underset{0}{\forall}$ & $\begin{array}{l}\mathscr{R} \\
0 \\
0 \\
0\end{array}$ & $\stackrel{\text { fo }}{0}$ & 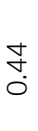 & ¿ृ \\
\hline 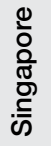 & $\begin{array}{l}\bar{\infty} \\
0 \\
0\end{array}$ & $\begin{array}{l}\infty \\
\infty \\
0\end{array}$ & $\begin{array}{l}\infty \\
\infty \\
0\end{array}$ & $\begin{array}{l}\mathscr{Q} \\
\stackrel{0}{0}\end{array}$ & $\begin{array}{l}\mathscr{D} \\
\infty \\
0 \\
0\end{array}$ & $\begin{array}{l}\text { Oे } \\
\text { Oे }\end{array}$ & $\begin{array}{l}\bar{\alpha} \\
0 \\
0\end{array}$ & $\begin{array}{l}\frac{\pi}{\omega n} \\
\frac{\pi}{\pi} \\
\frac{\pi}{2}\end{array}$ & $\begin{array}{l}\hat{\omega} \\
0 \\
0\end{array}$ & $\begin{array}{l}\hat{f} \\
\dot{0}\end{array}$ & $\stackrel{+}{\stackrel{0}{0}}$ & $\stackrel{8}{\bullet}$ & $\begin{array}{l}\text { fo } \\
\text { o }\end{array}$ & $\begin{array}{l}\infty \\
\stackrel{\infty}{*} \\
0\end{array}$ & \begin{tabular}{l}
$\infty$ \\
$\stackrel{\infty}{0}$ \\
\hdashline
\end{tabular} \\
\hline
\end{tabular}

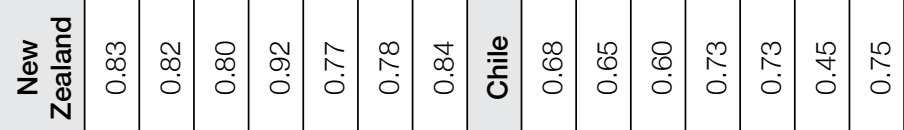

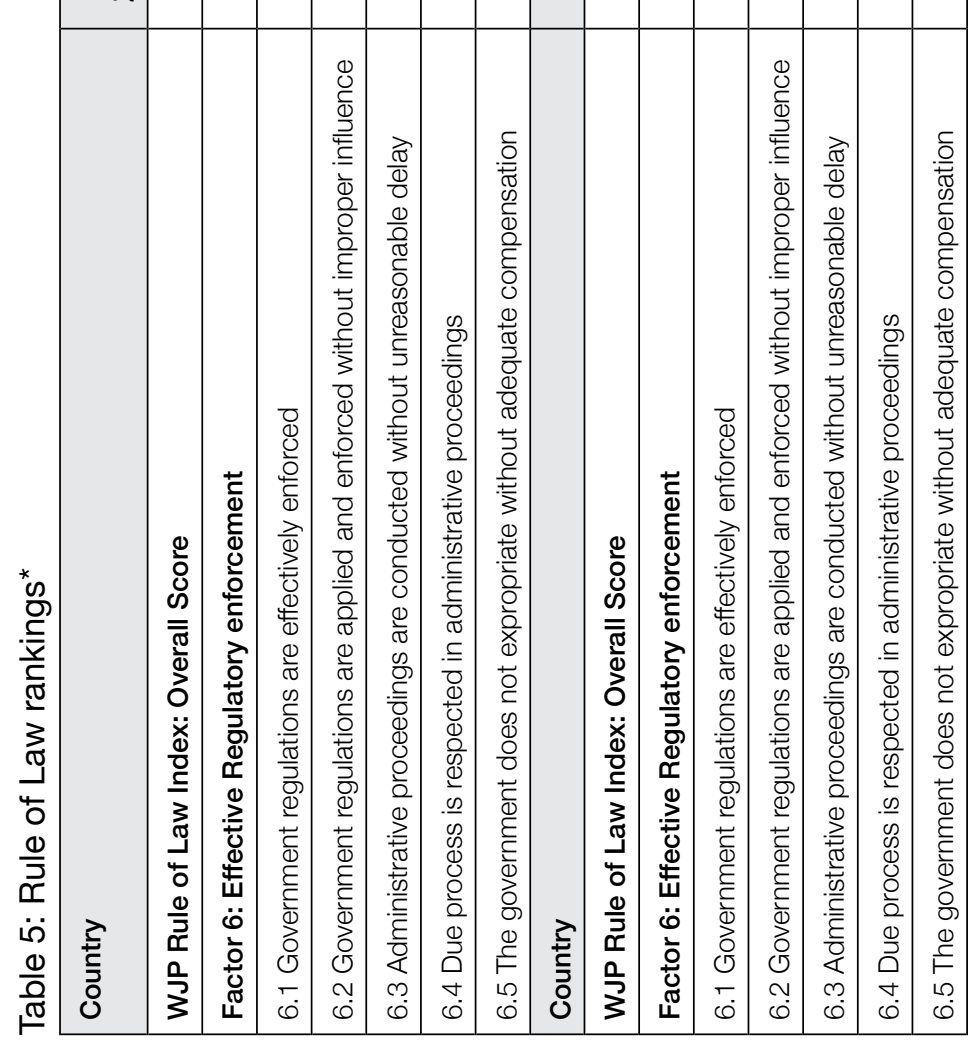


Thus, it is perhaps fair to assume that the ISDS would have been a heated issue for China, and it is possible that China would have fought for many exemptions, as in the case of Australia, Mexico, Peru and Vietnam. However, China has been signing agreements that include the ISDS clause over the last 15 years (Financial Times 2014); the China-New Zealand FTA is just one such example. In fact, in 2012, Ping An, a Chinese insurer, filed for a large investment treaty claim against Belgium (Financial Times 2012). Thus, the ISDS would have been a double-edged sword. While the ISDS is seen to be favourable for Chinese investment abroad, it reduces the authority the government has over the multinationals at home.

\section{Conclusion}

Removing obstacles to trade and investments, whether through reducing import duties, harmonising standards, eradicating quotas, protecting firms against intellectual property infringements, creating a level playing field for both domestic and foreign firms, and other initiatives, is known to increase the flow of goods, services and capital between countries. Not surprisingly, free-trade agreements have proliferated, particularly since the WTO has failed to initiate any significant negotiations since the Doha rounds. The TPP is yet another of the many FTAs signed in recent years.

Our analysis of China's trade data shows that China will lose out by not being a party to this agreement. Countries with similar capabilities - Japan and South Korea on the higher end and Vietnam on the lower end, for example - will be able to divert some trade away from China. China has also lost an opportunity to sign an FTA with the US. However, no country can ignore China when it comes to trade and investment. The sheer size of the economy and the waves of outward foreign direct investment (FDI) that it generates are important enough to ensure that economic relationships with China remain relevant. The fact that China already has, or is negotiating, trade agreements with nine of the 12 TPP members is a valid testament to its continued importance. Nevertheless, it is important that China builds up its productivity to ensure that it is able to compete with TPP members for market share.

This is a lost opportunity for China to commit to an improvement in the general trading and investment climate. The TPP offers member countries a roadmap and a time schedule to reform the business environment to one that is more competitive. It is a lost opportunity for China to give fresh impetus to its dwindling export sector (Financial Times 2016). 
But China has always reformed using its own timetable. Since the TPP is essentially a trade agreement with the US, following a specified TPP schedule could be seen as the US dictating reform in China. For a country that is establishing its legitimacy as a global economic power, China has to write its own future. The rules of the TPP may not fit the current state of the Chinese economy as they could be seen to be diluting the sovereignty of the government. China has to mould a domestic economy that is large enough to withstand any global economic slowdown. To create that domestic economy, certain features of the 'old' economy may still be required.

\section{References}

De Groot, H., Linders, G.J., Rietveld, P. and Subramanian, U. 2004, 'The institutional determinants of bilateral trade patterns', Kyklos 57(1): 103-23.

De Jong, E. and Bogmans C. 2011, 'Does corruption discourage international trade?', European Journal of Political Economy 27(2): 385-98.

Drahos, P. 2016, 'China, the TPP and Intellectual Property', IIC - International Review of Intellectual Property and Competition Law 47(1): 1-4.

Farrell, H. 2015, 'People are freaking out about the Trans Pacific Partnership's investor dispute settlement system. Why should you care?', The Washington Post, www.washingtonpost.com/news/monkey-cage/ wp/2015/03/26/people-are-freaking-out-about-the-trans-pacific-partnershipsinvestor-dispute-settlement-system-why-should-you-care/.

Financial Times 2012, 'Tussle with Brussels', 24 September.

_ 2014, 'China has already been signing agreements with strong ISDS mechanisms', 28 October.

- 2015, 'China cautiously embraces privatisation of state-owned enterprises', 25 September.

— 2016, 'China imports and exports slump in January', 15 February.

Hsu, S. 2015, 'China and the Trans-Pacific Partnership', The Diplomat, 14 October; thediplomat.com/2015/10/china-and-the-trans-pacific-partnership/.

Jandhyala, S. 2016, 'Why do countries commit to ISDS foe disputes with foreign investors?', AIB Insights 16(1): 7-9. 
Petri, P.A. and Plummer, M.G. 2016, 'The economic effects of the Trans-Pacific Partnership: New estimates', Working Paper Series WP 16-2, Washington: Peterson Institute for International Economics.

Petri, P.A., Plummer, M.G. and Zhai Z. 2014, 'The effects of a China-US Free Trade and Investment Agreement' in Bergsten, C.F., Hufbauer, G.C., Miner, S. and Moran, T. (eds), Bridging the Pacific: Towards Free Trade and Investment between China and the United States (Washington: Peterson Institute), pp. $31-84$.

Sauvant, K.P. and Chen, V.Z. 2014, 'China's regulatory framework for outward direct investment', China Economic Journal 47(1): 141-63.

Shirazi, M. 2012, 'The impact of corruption on international trade', Denver Journal of International Law and Policy 40(1-3): 435-46.

UNITAID 2014, The Trans-Pacific Partnership Agreement: Implications for access to medicines and public health, World Health Organization.

$\mathrm{Yu}, \mathrm{H}$. 2014, 'The ascendency of state-owned enterprises in China: Development, controversy and problems', Journal of Contemporary China 23(85): 161-82. 
This text is taken from Agenda, Volume 23 - Number 1, 2016, edited by William Coleman, published 2016 by ANU Press, The Australian National University, Canberra, Australia. 